MA MAJOR RESEARCH PAPER

\title{
Mobile Technology: Private Talk, Public Life and the Shrinking Commons
}

\author{
Savi Pannu \\ R. Bruce Elder, MRP Supervisor (Ryerson) \\ Steven Bailey, Second Reader (York)
}

The Major Research Paper is submitted in partial fulfillment of the requirements for the degree of Master of Arts

Joint Graduate Programme in Communication \& Culture

Ryerson University - York University

Toronto, Ontario, Canada

April 28, 2005 
"The important consideration is that opportunity be given to ideas to speak and to become the possession of the multitude. The essential need is the improvement of the methods and constitution of debate, discussion and persuasion. That is the problem of the public." John Dewey, The Public And Its Problems

\section{Introduction}

In the field of Communication studies, mobile technology is still a relatively new area of study with scholarly research just beginning to address this rapidly growing field. Because this technology is continually evolving, as is the way in which people are starting to use it, much of the research remains inconclusive as to any predictions of how this technology will to be used. In the meantime, much has been made about mobile technology's potential to change the way we interact and communicate with one another, and how these changes might have the ability to alter social relations forever. What I would like to examine are the locations where mobile technology and social relations intersect, and the manner in which the two inform each other. More specifically, I would like to focus on the areas where mobile technologies (cell phones, Blackberries, text messaging) affect social life, such as collective behaviour, political action, as well as public sphere and public space issues. Much has been made about the supposed benefits of technology and its potential to collectivize, politicize and, above all, 
mobilize our society. However, is this constant telephony really living up to this potential? In an environment already saturated with communication technology, billion-dollar advertising expenditures and media multinationals, will the addition of new technologies benefit those seldom heard or only add to the white noise?

In order to fully understand the implications of mobile technology within social relations, a discussion of the state of civic life as framed by issues of private and public sphere is unavoidable. In this age of high capitalism, much has been written about the demise of the Enlightenment project and its apparent failure to adequately address contemporary questions of power relations, gender and sexual politics as well as what it means to be a citizen in the age of political, social and economic globalization. While universal concepts of civic identity began to be renegotiated in favour of a more particulate approach, social democratic life became more and more inundated with corporate agendas of privatization and its bottom-line rhetoric. According to cultural and educational theorist Henry Giroux, "increasingly, notions of the public cease to resonate as a site of utopian possibility, as a fundamental space for how we reactivate our political sensibilities and conceive of ourselves as critical citizens, engaged public intellectuals, and social agents" (Giroux, xii).

In his recent book, Public Spaces, Private Lives: Beyond the Culture of Cynicism, Giroux discusses this decline of civic participation in the democratic process. He comments on the erosion of public values at a time when they are most in need of fortification, and identifies the problem as one that originates in a vision that refuses to see democracy without equating it with consumerism, 
market relations and privatization, where "public service and government intervention are sneered upon as either bureaucratic or a constraint upon individual freedom" (Giroux, Xv). In fact, it is precisely this obsession with individual freedom that has come to define our present social moment, where essentially we equate democratic participation with consumer choice. As evidenced by much of the marketing in the industry, one of the most important features of mobile technology is its ability to be individually customized by its owner. So, not only is the user able to receive digital information on their phone, laptop or BlackBerry, they are also able to limit, or chose the content, making it specific to their needs. As Roger's AT\&T confidently declares in their advertising, "You Control Your Internet". Consequently, Internet usage becomes more an exercise in consumer interest than a portal to potential engagement with civic issues and information.

\section{Literature Review}

The question of mobile technology and its effect on the public sphere is a broad one, with many theoretical concepts to consider. Any discussion of the public sphere would not be complete without an examination of the ways in which individuals participate in discourse and the formation of public opinion. Habermas' seminal work The Structural Transformation of the Public Sphere (1989) defines the public sphere as an arena in which issues can be rationally discussed and public opinion is formed. According to Habermas, the 'public sphere' came into being largely due to the emergence of the petit bourgeoisie as 
well as an increased amount of leisure time (which allowed them to engage in public discourse) that they started to have as a direct result of the switch from a feudal to a market-based economy. However, with the advent of mass media and communications and the shift towards populism, Habermas theorized that the public sphere has become too fractured. While other theorists have criticized him for his overly rational approach to social relations as they inform public discourse, various research has been done around the notion of public sphere and whether it does in fact exist. Marxist approaches offer historical arguments as to why his analysis of the media and the transformation of the bourgeois public sphere are inaccurate and misleading (Curran, 1991; Norris, 2001). Still others offer arguments as to the possibility of a participatory public sphere through the possibilities of new technologies like the Internet (Street, 1997; Pal, 1999; Fletcher and Everett, 2000).

While research on mobile technologies and their effects on social relations is a relatively new area, there are a few scholars that have done significant work in the field. Robert Putnam's $(1996,2000)$ examination of American civic organizations (church groups, bowling leagues, etc) indicates that there has been a marked decline in civic engagement from the 1960 s onwards. Other theorists have indicated that an increase in on-line community participation is also leading to yet further disengagement from civic and social life (DiMaggio, Hargittai, et al., 2004; Lin, 2001). Theorists such as Howard Rheingold $(1993,2002)$ have actively promoted the possibility of collective action through the use of technological devices, whereas others are less optimistic about this trend 
(Gergen, 2002). What seems to be indicated, however, is that communication technologies are significantly changing social relations (Katz, Rice et al., 2001) and the effects of these technologies on civic engagement are leading to a deterioration of social capital (Graber and Bimber, 2001; Giroux, 2001).

\section{Public Sphere and the Citizen}

With new digital technologies changing the way news is produced and reported, continuing questions surrounding the media as fourth estate and the formation and mediation of public opinion remain at the forefront. Jergen Habermas' seminal work The Structural Transformation of the Public Sphere (1989) introduced the idea that there once existed a public forum in which issues could be rationally debated for the public good, placing an emphasis on transparency and accountability of institutions and the elite to the rest of society. While Habermas' work was eventually criticized as problematic in certain aspects, his study certainly spurred much thought as to how the public sphere in fact operates. Classical liberal theory defines the public sphere as, "the space between government and society in which private individuals exercise formal and informal control over the state" (Curran, 29). The media are pivotal in this process, as they distribute information as well as help in facilitating the formation of public opinion. Within this role, the media as a 'fourth estate' remains an independent forum of debate, as well as provides access for public opinion to shape governmental affairs. The problem with this approach is that it emphasizes relations between the individual and the state, without acknowledging how power 
is exercised through capitalist and patriarchal structures. Access to public opinion is separated by social cleavages that privilege certain individuals and groups over others. Consequently, issues of representation and access are never addressed. The radical democratic approach to the media as public sphere goes far beyond the notion of the media as a politically neutral watchdog as put forth by classical liberalism. From this perspective, the media is seen as a "battleground of contending forces", whose mediation and response to this conflict directly affects the balance of social forces and consequently "the distribution of rewards" in society (Curran, 29). As a result, the media must represent all significant interests in society in order to fulfill its democratic role as well as enable an equal contribution to public debate and the formation of public policy. The wholesale failure of the mass media in accomplishing such goals has led to a burgeoning independent media culture that owes much to the development and usage of the Internet.

Many theorists have looked towards the Internet as an answer to the drawbacks of the previous models of the public sphere. Unlike the mass communication of radio or television, the World Wide Web potentially offers entry-level participation to literally anyone with a computer and an Internet connection. Similar to Habermas' idealized Commons of the seventeenth and eighteenth century that emphasized "rational debate", the Internet as an electronic public sphere provides a forum for discussion that often follows certain rules and guidelines in the from of 'netiquette' (what is deemed as acceptable or not while engaged in discussion or commentary), which most participants on list- 
servs, blogs and on-line communities adhere to. As political economists and media studies theorists had shown the mass media to be just as susceptible as any other corporation towards political and market-driven imperatives that are most often at odds with the public interest, the seeming impartiality and participatory nature of the Internet prompted high expectations for the new medium. At its inception and as yet relatively untouched by the hands of corporations and advertisers, the Internet could potentially become a vast resource of information begetting an era previously unseen levels of communication, effectively demolishing social and economic barriers. These visions of mass participation in public sphere issues, as it turns out, were probably a little too optimistic. The World Wide Web has mushroomed in the last decade: "from fewer than twenty thousand web sites in 1995 to over ten million in 2000 representing over two billion web pages, with as many as two million pages added daily" (DiMaggio et al, 35). Media theorists Doris A. Graber and Bruce Bimber have studied this explosion in Internet use and yielded some interesting results. In their paper "The Internet and Politics: Emerging Perspectives", after looking at individual participation in political campaigns in the real world as well as the virtual one, the two conclude that the Internet is most effective in strengthening communication among individuals or groups, rather than bringing new audiences into the fold (Graber, Bimber et al, 113). Specifically with respect to political campaigns, the researchers found that candidates who used on-line campaigning tactics did not appear to have any significant success in reaching new and potential pockets of support. Graber and Bimber state the following: "the 
use of the Internet supplemented rather than supplanted traditional campaign activities by candidates. The most significant change had occurred in the relationship between campaigns and the candidate's core supporters" (Graber, Bimber et al, 113). While use of the Internet continues to increase daily, it appears that the correlation between usage and public sphere participation is tenuous at best.

\section{We Are All Connected'}

In an increasingly accelerated culture that requires equal dedication to work, socializing and relentless "keeping in touch" as a precursor to success, the demand for mobile technology - which allows us to accomplish these neverending tasks - has reached a fever pitch. Greater demands on time, coupled with the sense that we need to accomplish more on a daily basis to be successful and efficient, while at the same time be able to enjoy leisure activities with family, friends and loved ones, have allowed for an unprecedented penetration of cell phones, BlackBerries (Personal Digital Assistants) and other technologies into our lives. The increased proliferation of these new gadgets into our daily lives has affected our interactions with one another as well as social relations on a larger scale. The UN has recently reported that currently, 48 percent of the world's population lives in urban areas, and that by 2007 this number will have climbed to over 50 percent. This will be the first time in history that the world's population will have more urban residents than rural (Honoré, 28). With increasing numbers of people flocking to the fast-paced, technologically driven 
rhythms of modern capitalism and urban life, the expectation to keep up and keep moving to make a living has been heightened to an alarming degree. In major urban centers where time literally is money, multi-tasking has become a necessity, especially when working long hours or enduring lengthy commutes. Checking-in with family or friends while catching quick updates of the daily news headlines, stock reports and sports highlights while listening to an MP3 digital music track or making an online payment has become a regular part of our daily lives. Our dependence on these gadgets allows us to keep on top of everything while on the go. With so many demands being made on our time, it's no wonder that any concern beyond the immediate are frequently put on the back burner so to speak, if not disregarded wholeheartedly.

Recognizing the demand for such products, mobile technology companies have flooded the market with products, and have convinced us through ubiquitous advertising that, "we are all connected" - or at least, we should be, according to Bell Mobility. And if simply having a quick chat is not enough, we must also be exchanging photos, forwarding jokes and (until recently) sharing music files, because that's has now become part of "keeping in touch". Taking this idea of connection to another level, digital networks like Dodgeball.com offer a service that allows subscribers to be alerted when one of their 'contacts' is within a tenblock radius. The service also allows this information to be sent to people that the subscriber desires to meet, provided that they have been added them to their 'contacts' list. According to the developers of Dodgeball.com, the purpose of such a network is so that one can keep in touch with friends at any given moment and 
location. One might assume that this level of interconnectivity would bode well for the strengthening and growth of social capital, yet this has not been the case.

\section{Social Capital and Democracy}

Social theorists have identified the concept of social capital as integral to democratic practices, on which a strong civil society depends. In his book, Bowling Alone: The Collapse and Revival of American Community, Robert Putnam explains the concept of social capital as one that is defined by, "social organization such as networks, norms, and social trust that facilitate coordination and cooperation for mutual benefit" (Putnam, 67). Putnam has diagnosed the current political culture of America as being in "democratic disarray". He feels that this current political situation is marked most prominently by general disengagement and an overall decline in membership within civic organizations. Media theorist Robert McChesney concurs with this notion, writing that, "a vibrant political culture needs community groups, libraries, public schools, neighborhood organizations, cooperatives, public meeting places, voluntary associations, and trade unions to provide ways for citizens to meet, communicate, and interact with their fellow citizens (Chomsky, 11). While our mobile technology might keep us in contact with those already in our network of social trust, it simultaneously severs our participation to the larger social sphere. Putnam cites that the number of people who socialize with their neighbours more than once a year has declined by 20 percent in the past three decades. A similar situation appears to have occurred in Great Britain, where "35 percent of Britons do not even know their 
neighbours' names" (Honoré, 92). This is not surprising, as the idea of mobility extends itself into individual lifestyle, where employment within the global economy often includes the possibility of multiple relocation according to corporate needs. Dubbed the "re-potting hypothesis", research has shown that residential stability is associated with greater civic engagement, leading theorists to believe that mobility, not unlike the re-potting of plants, might create an adverse effect (Putnam, 75). Putnam also explains that social capital is absolutely necessary in building networks of social trust that amplify reputations and resolve dilemmas so that collective action can occur.

In such a process, when economic and political negotiation is embedded in dense networks of social interaction, incentives for opportunism are reduced. At the same time, networks of civic engagement embody past success at collaboration, which can serve as a cultural template for future collaboration. Finally, dense networks of interaction probably broaden the participants' sense of self, developing the "I" into the "we," or (in the language of rational-choice theorists) enhancing the participants' "taste" for collective benefits. (Putnam, 74)

Most importantly, the horizontal nature of social capital and its ability to manifest itself through a variety of non-market organizations and institutions allows for a more humane way of living. Left with the alternative, we would continue to witness the shift from citizens to consumers, from communities to corporate spaces and an increasingly atomized society where disengaged individuals feel that the only power they might still have can only be exercised through consumer choices. 
While there is nothing inherently wrong with having a multitude of choice when making purchasing decisions, the problem begins to arise when other areas of social and civic life are seen under the same lens. One of the major criticisms of the Internet is based in its capacity to act as a platform where public sphere issues can be discussed and evaluated. The implications of increasing commercialism point primarily towards the functions and uses of the technology itself. Service providers, sensing the integral roles in which the Internet and its associated technologies have played in the establishing of social identities, have progressively started to offer more systems of unlimited individual filtering in order to meet user needs. Instead of simply logging on and surfing the Net for random information, users now chose from selected bookmarks that offer information that has already been pre-filtered to individual tastes and needs. For example, the provider MSN is now MyMSN, and greets users with their own 'webpage' with specific news, weather, business, entertainment or shopping information that is recorded during the users previous visits to the site. If the most viewed link happens to be 'Celebrity Gossip", MyMSN will automatically send updates that contain such information directly to your MyMSN email account and provide further links to similar content. The problem with this type of Internet customization is that repeated exposure to pre-filtered content creates a situation where information is selected by private interests, often to the exclusion of information about greater social issues. In a system where individuals make choices among innumerable options based only on their private interests, users will fail to learn about topics and views from which they may not personally 
benefit, but would certainly serve the greater good (Sunstein, 102). While individual tastes would be satisfied much more fully, this trend towards customization drives a wedge between individual and collective interests. Encouraging cyber-balkanization, this systematic filtering of all that has no interest (and therefore no value) to the individual can only add to individual alienation from society. If this continues to be the case, the future of collective action may look bleak indeed.

\section{The Phenomenon of 'Absent Presence'}

Not only do these factors affect the way we retrieve and process information around us, the way we interact with one another has begun to change as well. Communications scholar James Katz at Rutgers University has written extensively on mobile communications and the negotiation of public space and private relationships. He recently edited Perpetual Contact: Mobile Communication, Private Talk, Public Performance, in which many issues surrounding mobile telephony are explored. Appearing in Section Three, a paper titled the "Challenge of Absent Presence" by noted psychologist Kenneth G. Gergen makes a strong case for the role mobile phones and technologies play in destroying spontaneous interactions in public spaces. He discusses how these technologies have encouraged us to connect individually while at the same time disconnecting socially, in the process ceding much that was civil and civilized about the use of public space. Gergen coins the term 'absent presence' to 
describe a phenomenon that we are beginning to see more and more on every street in every city. He describes it in the following way:

One is physically present but is absorbed by a technologically mediated world of elsewhere. Typically it is a world of relationships, both active and vicarious, within which domains of meaning are being created and sustained. Increasingly, these domains of alterior meaning insinuate themselves into the world of full presence - the world in which one is otherwise absorbed and constituted by the immediacy of concrete, faceto-face relationships. (Gergen, 227)

Gergen too, sees problems with perpetual contact among closed social systems. He observes that we are strengthening and increasing our interactions with people we already know at the expense of those we do not, contributing to the erosion of public trust among strangers in a public, social setting. Inadvertently, the mobile user retreats into their own private space of conversation or communication, unable to respond to social overtures and often becoming oblivious to their voice level or the appropriateness of their conversational subject matter. Hence, public space is transformed from one of civilized, tolerable social interactions and everyday decencies into unwilling aural participation in private spheres, as well as a dehumanization in which the failure to acknowledge others creates feelings of frustration and insignificance. Gergen sees the consequences of such widespread behaviour in the following ways: "the erosion of face-to-face community, a coherent and centered sense of self, moral bearings, depth of relationship, and the uprooting of meaning from material context: such are the repercussions of absent presence" (Gergen, 236). 
Another drawback is that perpetual contact through mobile technology allows us to strengthen and increase our interactions with people already within our system of interpersonal relationships, while at the same time taking away from the benefits of spontaneous public interactions which work towards building social trust and civic accountability. This narrowing of interaction contributes to a weakening of public trust and the creation of culture of fear in which "the unknown" triggers larger social anxieties. Those anxieties, in turn, drive us to avail ourselves to mobile technology, which allows us to be accessible at all times, making trust relationships between individuals flourish while decreasing public trust on the whole. An example of this is evident in the increasing numbers of parents who cite safety reasons as the primary motivator for providing their children with mobile phones. Interestingly, while the introduction of this technology tends to alleviate some of the parental anxiety, in many cases it has heightened safety anxieties in children (Altheide, 124). Additionally, as users cite safety as one of the main reasons for keeping their mobile gadgets handy, how effective they are in times of emergency is a hotly debated topic. For example, cell phone usage during the events of September 11, 2001 showed that while helpful during the unfolding of events, cellular customers encountered frustrating communication breakdowns as cellular carriers shut down, unable to handle the tremendous influx of calls in the aftermath of the attacks. In an already heightened culture of fear (especially after the terrorist attacks), more civic interaction within public spaces can only help in the avoidance of an atmosphere of paranoia and mistrust. 
Gergen goes on to stress the dangers of technological mediation not only on the individual user (in their inability to control their own accessibility by allowing mobile technologies to make them 'reachable' at all times) but also in the way users allow the technology to play a part in their identity formation. $\mathrm{He}$ argues that those who persistently engage in relationships that rarely involve face-to-face communication are at risk of alienating themselves from local, civic life, as it become less relevant to personal interest and primary sources of meaning. At its worst, he contends that "when the command of the local is destroyed, the stage is set for flagrant violations of its moral standards - for indulgence in child pornography, the mass suicide of the Heaven's Gate movement, or the massacre at Columbine High" (Gergen, 232). While these events are by in large isolated and not consistent with the norm, the point to be taken from this is that identity formation ceases to be influenced by the everyday interactions with family and community and can potentially create a cultural condition in which our identities are "increasingly situated, conditional and optional" (Gergen, 234). All of a sudden, the day-to-day activities of life begin to lose meaning and the skills required to engage in effective exchanges in daily relations diminish. On the whole, it is surmised that 'absent presence' has become an unfortunate side effect of mobile communication and is a good indicator of how mobile technology might be changing people's behaviour, and consequently the places in which we work and live.

\section{Text and the City}


However, despite the more worrisome aspects of mobile technology and its effects on social relations, there are some who think that these devices have the potential to positively influence by encouraging "collectivity through connectivity". Self-proclaimed 'futurologist' and social theorist Howard Rheingold is certainly one who thinks that this technological convergence in the form of mobile communications devices will herald a new and unprecedented age of global interconnectivity. In his 2002 book SmartMobs: The Next Social Revolution, Rheingold examines the notion of pervasive computing and the potential for unprecedented opportunities to enhance social capital in embracing "technologies of cooperation" and theorizes the presence and implications of new trends in social interaction in the form of 'smart mobs' and 'flash mobs'. He describes the 'smart mob' phenomenon as "people who are able to act in concert even if they don't know each other. The people who make up smart mobs cooperate in ways never before possible because they carry devices that possess both communication and computing capabilities" (Rheingold, 12). According to Rheingold, smart mobs will enable new forms of social power and new ways to organize interactions, and that the ways in which people "meet, mate, work, fight, buy, sell, govern and create" will be fundamentally altered mostly for the better (Rheingold, 13). This type of action and social organization is enabled through pervasive communication via cell phones, pagers, and handheld computers. The pervasive technology that will enable all kinds of new communication possibilities is sure to have many effects on the way we live our lives, and 'smart mobs' could turn out to be one of them. 
Already, examples of social organization through pervasive technology have been identified. Text messaging or Short Message Service (SMS) as it is known in the mobile world, is now becoming one of the primary ways that people use their mobile phones. Cheaper than an actual phone call that quickly depletes paid minutes, texting has come to replace emailing as a quicker alternative, as users can avoid the hassle of sifting through their overflowing inboxes by simply keeping their phone on. Almost like a grown-up version of the age-old note passing in classrooms, many use texting to pass the time during lengthy and less than engaging business meetings, conferences or even university seminars. Those who use SMS are hard to miss, their thumbs twiddling away at tiny keypads in any given public space. In Japan, some have become so proficient at the practice that they are able to text from their phones without even looking, earning the moniker of oyayubisoku, a Japanese nickname meaning 'thumb tribe' (Rheingold, 4). What seems to be one of the most attractive features about this type of communication is that individuals are able to conduct conversations with one another that cannot be overheard, unlike the less-than-private nature of cellular communication. Additionally, unlike the email process, these interactions are less formal in structure. As a result, SMS became hugely popular with teens, as they could keep in touch with those in their peer group and at the same time freely talk about anything without fear of being monitored, especially when they are at home or spending time with their families. This is especially true of adolescents in Japan and Finland - both nations where mobile technology penetration rates are among the highest on the planet.

Texting, however, has quickly become as popular with adults as with adolescents. The furtive, almost clandestine nature of texting has given rise to networks of lying, 
where people send out mass text messages to thousands of potential collaborators asking for help. When a willing helper responds, the sender and helper craft a lie, and the helper then calls the victim with an excuse - not unlike having a friend forge a doctor's note for a teacher in the pre-digital age. Organizations such as The Alibi and Excuse Club as well as Soundster are recent examples of such networks, and are actively being used by people in the United States, Europe and China. Soundster, a particularly amusing application, when downloaded to one's phone, allows for various sounds to be inserted into the user's mobile conversation in order to mislead the person who they are talking to (boss, wife, parent) as to their whereabouts. Besides these somewhat improper applications of texting and mobile technology, Rheingold observes that they have also allowed for a "softening of time" - meaning that users have started to eschew punctuality in favour of a more fluid approach to meetings and appointments. Plans of where and when to meet will often be changed moments prior and even while en-route to a meeting place, giving an appearance "like a school of fish", changing directions in mid-stream (Rheingold, 13). This 'hyper-coordination' is a trend that is particularly exemplified by younger users. Finnish mobile researcher, Pasi Mäenpää describes how texting is changing the way we meet and organize:

The mobile telephone is evolving into a kind of remote control for people's lives. Our technology-assisted and hyper-informated pace of living apparently now requires further technology, in order for the hyper-informated to control our own lives. And controlling our lives through mobile devices involves scheduling future activities (Rheingold, 194).

What Mäenpää is saying is that the way in which we have always understood scheduling for future meetings, be they business or social, is in fact being changed. 
Mobile technology has allowed a flexibility of time and place which tends to blur our plans and visions for the future, leaving us with only an approximate understanding of things while eroding our sense of everyday structure. Not only is our perception of time significantly altered, "the notion of a previously produced, organized future is replaced by a sliding sense of time which is constantly tilted towards the future" (Rheingold, 194). Again, the obsession with time is highlighted as a social symptom of the increasing use of mobile technology - this time forsaking the present for anticipated activities in the future.

To be fair, there are some truly inspired uses of this technology that merit further discussion, as the social implications of such uses could be extraordinary. Rheingold has documented many instances of collective action and mobilization where mobile technology has been used as a tool of democratic action. This type of social organization has even been helpful in collectivizing people for a common purpose. For example, in January 2001, one million Filipino protesters helped to force President Joseph Estrada from power. Their collective protest was catalyzed by a text-message summoning them to a centralized location: "Go 2EDSA. Wear Blck" (Rheingold, 158). Dubbed "People Power II" (the first "People Power" being the ousting of President Marcos in 1986) the demonstrations of 2001 were spurred on by the broadcasting of text messages by opposition leaders urging the public to take action during the impeachment trial of President Estrada. Rheingold asserts that due to text messaging, twenty thousand people turned up to protest in the following seventy-five minutes after the broadcasts were made (Rheingold, 160). Within twenty-four hours, it is estimated that one million people converged at the central area. In mentioning the massive non- 
violent demonstrations in 1986 that brought down the Marcos government, Rheingold is obviously acknowledging that there is a history of collective action among the Philippine people that preceded the advent of mobile technology. However, he emphasizes the very rapid distribution of information that was accomplished through texting - a practice that had be entrenched within the culture since 1995, when SMS was introduced as a free feature for mobile users. Since wire-line telephones are more costly than mobile service, many people were early adopters of the technology simply for this reason. While a charge of SMS use was eventually introduced, the practice continues to be very popular in Philippine society. SMS also figured prominently in the recent SARS crisis in China, where millions of text messages were sent as a way of disseminating information and circumventing the government censure surrounding the outbreak of this deadly virus. One can only surmise how explosive such an outbreak might have become if absolutely no information was available on how contraction of the air-borne respiratory virus could be avoided. However, the trouble with this type of relaying of information is that it is virtually impossible to vet, making any warnings and precautionary advice difficult to endorse. Even though cooperative effort may be the goal, often the message can become unraveled as a result of unregulated participation - not unlike the garbled end-result of the children's game 'Telephone'. Additionally, to solely depend on these 'networks of trust' might give rise to opportunities for those with darker interests in mind (terrorist, organized criminals, etc).

Another example Rheingold talks extensively about is the collective action of World Trade Organization (WTO) demonstrators during "The Battle in Seattle", who relied on wireless telephones to coordinate their actions and evade barricades and 
arrests. According to Rheingold, the Manila protesters and the Palm Pilot-wielding demonstrators who disrupted the WTO's 1999 Seattle meeting were early adopters of the smart mob, because their organizational ability and ad-hoc alliance was formed fleetingly by people who shared a common, immediate goal and could communicate instantaneously. The implications of such an immediate collectivized action would have no doubt caught the attention of Debord and his Situationist strategies had he been alive. With obvious parallels to the 1968 student protests in Paris, the organization and implementation of the anti-globalization movement in all its forms (be they artistic or for protest purposes) owes much to the politicized actions and beliefs of the Situationist International. Many avant-garde movements, above all the Situationists, used their art and actions as strategies for entering into the public discourse and creating a voice in direct opposition to bourgeois or ruling-class ideology. This populist impulse was an appeal to the average person and their everyday existence and wanted to appeal to those looking for meaningful moments of real participation in social relations. In its ability to connect and collectivize total strangers seeking commonality, the smart mob also seeks to satisfy this same urge. Because the history of political and other collective actions has always centered around communications technologies and their ability to organize, communicate and disseminate, the notion of smart mobs is a powerful one, conjuring up the possibility of real social revolution if adopted in a widespread, politicized way.

While mobile communication devices offer new strategies of collectivization, the other side of this coin would consider how electronically equipped people interact with this electronically equipped terrain. Rheingold 
brings up the notion of consumer compliance towards digital surveillance for the sake of convenience and accessibility. He describes this scenario: "In the recent past, it was said that digital information technology, such as the magnetic strips on credit cards, leaves a "trail of electronic breadcrumbs" that can be used to track individuals. In the future, the trail will become a moving cloud as individuals broadcast information about themselves to devices within ten yards, a city block, or the entire world." (xxi) Consumers will trade privacy for convenience as digital advertisers match merchandise with individual consumer taste with increasing accuracy. Instantly, issues of surveillance and social control through digital/electronic tracking emerge. Scenarios where unintended parties apprehend personal information pose threats to security, among other things. As a result, boundaries between public and private spheres begin to erode, problematizing the relationship between trust, reputation and the social contract.

To explain his idea of mobile communication technologies creating communities of interest, Rheingold argues that powerful, fast, and ubiquitous computing devices will permit new forms of cooperation to develop. Because people come to cooperate based on such factors as shared history, apparent trustworthiness, and social reputation, he hopes that mobile communications will create an environment where "epidemics of cooperation" can flourish among groups concerned with the public good or otherwise. He uses gaming theory to explain how cooperative behaviours are able to exist and thrive: "Within a pool of entirely uncooperative strategies, cooperative strategies evolve from small clusters of individuals who reciprocate cooperation, even if the cooperative strategies have only a small portion of their interactions with each other. Clusters of 
cooperators amass points for themselves faster than defectors can. Strategies based on reciprocity can survive against a variety of strategies, and "cooperation, once established on the basis of reciprocity, can protect itself from invasion by less cooperative strategies. Thus the gear wheels of social evolution have a ratchet" (Rheingold, 45). Because cooperation is built on competition, the assumption is that "Cooperators who clump together can out-compete noncooperative strategies by creating public goods that benefit themselves but not the defectors. Therefore, reciprocity, cooperation, reputation, social grooming, and social dilemmas all appear to be fundamental pieces of the smart mob puzzle" (Rheingold, 46). Theoretically, in a gaming environment this works, however, when the realities of marginalization (both economic and otherwise) are brought into the fold, all of a sudden different behaviours are seen. What Rheingold and others believe when it comes to the proliferation of pervasive communications technologies, is that smart mobs will become a viable tool for collectivized, social action because of the inherent cooperative element that exists within virtual exchanges in the first place. Like the Situationist belief that the technology of capitalism can and should be used against itself, the possibilities that exist for mobile communications technologies is exciting, however, being able to afford and continually use such technologies creates a whole new arena of issues involving access and exclusivity.

Another exciting possibility to Rheingold is the emergence of peer-to-peer journalism, where 'roving reporters' converge on events that are being covered (or have been neglected) by traditional media outlets to provide an informational alternate to what is otherwise a media conglomerate monopoly. Specifically, a group of researchers 
and students from the Humanistic Intelligence Labs at the University of Toronto are mentioned. Professor Steve Mann and his students have been testing wearable computers called 'EyeTaps' which broadcast everything an individual sees and hears to the Internet. The idea behind this being that the footage would be captured and viewed by audiences as if they were actually there, thus providing an 'un-biased' account. This type of research has played an instrumental part in the newest online craze, 'blogging', the practice of keeping a weblog, and its mobile version 'moblogging'. In fact, Mann and his research team have been credited as the first mobloggers. When blogging first started to appear on the Internet, much of it was essentially posting one's diary or daily journal online for people to read and comment on. The practice quickly became commonplace as many different issue-specific blogs began to pop up, some even accepting sponsorship from corporations in exchange for posting their advertising and logos on sites with heavy traffic. Primarily link-driven, with postings that include commentary, personal thoughts and essays, blogs became popular due to their ability to constantly update their content with time-stamped posts by anyone who wishes to participate. Now with mobile technology like the BlackBerry, a personal digital assistant with mobile email capability, moblogging has elevated the frequency of updates, as users are able to upload information while they are on the go. Political campaigning, media programs and even corporations have all embraced blog culture, ostensibly because of its ability to represent unmitigated public opinion. However, this seems slightly suspect as there is no way to determine if the postings represent an accurate cross-section of society, thus casting doubt over the ability of blogs to become arbiters of public opinion. 
A recent case involving blogs and their growing significance in public affairs had to do with CBS anchor Dan Rather's reportage on the questionable military record of George W. Bush on the show 60 Minutes. Within hours, online forums and especially right-wing blogs such as Powerline were abuzz with people questioning the validity of the documents. By the very next day, speculation on the authenticity of the documents had reached such a degree that other major news networks began to pick up the story, while CBS rallied around Rather and his sources. The events that ensued, now referred to as 'RatherGate', culminated in the revelation that the documents were, in fact, forged, which many believe led to Rather's hasty announcement of his intention to retire from CBS. Many journalists have blamed blogging for continuing to fuel the fire on this story, which had a huge impact on the length of its play on newswires. One of the biggest criticisms seemed to be the blurring of the line between what is considered journalism as opposed to individual speculation and comment. Some media commentators have argued that if issue-based blogs begin to have any sort of clout within the media structure, the profession of journalism, one that is based (theoretically) on fairness, integrity and an obligation to inform the public, would be highly compromised. By many accounts, the conglomeration of media corporations over the past two decades has already compromised journalistic integrity, but opening it up further to issue-based, ranting forums might destroy any credibility the fourth and fifth estate might have ever had. Again, issues of regulation are highlighted as mobile technologies are starting to change the way individuals participate in the public sphere. Certainly, the ability of the individual to participate in on-line forums at any time and place is also changing the way news is made. With fewer filters and without the benefits of journalistic conventions and 
editorial standards, the electronic public sphere allows for information to develop and circulate widely - at times, leaving legitimate information open to wild speculation and rampant misinformation. Rheingold even mentions an instance where SMS was responsible for the spread of news of the Pope's supposed death, sending much of the largely Catholic Philippine population into mourning.

The public spheres created by the Internet and the Web are more than just parallel information universes that exist independently of traditional mass media. To the contrary, the gatekeeping capacity of the traditional press is weakened when information appears on the Net, often in breathless fashion, with fewer reliable sources, and little time to decide on its validity before pressures to publicize it in mainstream channels become intense (Graber, Bimber, et al, 106).

Closer to home, the on-going Gomery Inquiry is another example of rapid information sharing that has led to huge media coverage. Reacting to a court-imposed publication ban on the details of certain damning testimony, American bloggers published details from the testimony online, defying a Canadian court order that did not have any control over a trans-national electronic community. The availability of the information on the Internet, along with pressure from media lawyers was responsible for the partial lifting of the publication ban - which had mostly to do with the impartiality of witnesses should a criminal trial proceed. Interestingly, the blogs that published the banned testimony were the very same ones that were active during Rathergate, prompting the question of what might be the motivations of these blogs in the first place? Noting that many of these blogs are linked to right-wing online communities and to organizations such as FOX News, it is hard not to conclude that they might have an agenda with regards to mainstream news and its effect on political issues and, more importantly, public opinion. 
These two incidents are, perhaps, the best examples of how special interest groups are harnessing the potential of mobile technology and blog culture to participate in the electronic public sphere in their attempts to influence discussions on issues of the public interest. Certainly, blogging and moblogging are beginning to have an effect on how the media chooses to produce news - which, until recently, was essentially a closed system.

\section{The Roving Eye: Mobile Technology and Surveillance}

Because the history of political and other collective actions has always centered around communications technologies and their ability to organize, communicate and disseminate, the notion of smart mobs is an interesting one, however whether this phenomenon will be used in this manner remains to be seen. Rheingold's study of the smart mob phenomenon also describes darker uses of pervasive technology - specifically, the ongoing effort by corporations to add computing power to our environment in the buildings we occupy, the objects we buy, even the clothes we wear. In his article "From Mass Society to Perpetual Contact: Models of Communication Technologies in Social Context", James B. Rule poses the question of how long consumer participation in systems of perpetual contact will remain authentically voluntary. He points out that increasingly, the government and the private sector have started to pool informational resources on citizens/consumers and that this trend marks "a significant step in the movement toward...'total surveillance' - that is, a world in which every fact and every moment of every individual's life registers with a single, centralized agency of surveillance" (Rule, 248). Already, since the events 
of September 11,2001 , the notion of 'the anonymity of the city' has become a thing of the past and the increased usage of mobile technologies by vast numbers of the population is helping in the monitoring of public spaces and even the public sphere. Rheingold reports this about surveillance in cities:

In 2002, BBC News reported that the image of the average urbanite is caught on closed-circuit television cameras three hundred times a day. In 2001, Virgin Mobile admitted that they had stored the location records of every mobile call made by each one of its 1 million customers since the service was launched in 1999. During Super Bowl XXXV, seven months before the terrorist attacks on the United States made high-tech surveillance check-points a part of daily American life, the face of every person who entered the stadium was captured by digital video cameras and compared computationally to a database of wanted criminals. In March 2002, Motorola and Visionics, the company that created the Super Bowl facial recognition system, announced their intention to market mobile telephones that include real-time facial recognition capabilities to law enforcement personnel. (Rheingold, 185)

Alarmingly, the pattern towards increased surveillance only continues to be reinforced with the justification that this information is being collected in the name of safety - so that actions might be anticipated and that every eventuality can be planned for. However, with continuing amendments to the United States Patriot Act legislation, questions surrounding the encroachment on civil liberties begin to surface. Section 215, entitled the Library Provision, allows the government to scrutinize all records of library materials borrowed if any suspicion arises as to the users' affiliation with any type of terrorist organization. In addition, recent amendments have included the government's right to access and monitor messages left on personal answering machines. 
However, if you are simply the average citizen who goes about their business and has never had a brush with the arm of the law, you and your information are still being scrutinized. Unbeknownst to many of their users, mobile phones, BlackBerries and other mobile technologies have become tracking devices, with most of the new models containing GPS systems capable of receiving and sending signals that can accurately locate the user's exact location. Bluetooth, a new technology that is now becoming a standard feature in many mobile devices, provides a wireless way to connect and exchange information between various digital technologies. This technology allows various devices to 'talk' to each other when they come in range, even if they are not in the same room, as the connection is made through short-range radio frequencies. While Bluetooth may be helpful to its users for shifting information from computer to phone to Blackberry or other devices, there are growing issues surrounding the security of this technology and what it might mean for potential users. Wired's online magazine recently published an article about the compromised realities of Bluetooth technology and how susceptible they are to 'Bluetooth snooping' by those with a desire to commit identity theft, monetary theft or simply listen in on what you might be up to. Users' address books, contacts, information on computer banking, virtually any piece of information that is contained in any of a users' communication devices is potentially available to anyone with a basic understanding of computer networking. According to Wired, terrorism is not the only thing that should worry government officials, warning that Internet telephony, which is quickly being adopted as the standard for many large corporations, 
might be a far bigger nightmare. Because mobile technology is being used more frequently in concert with computers in the workplace and at home, new security concerns are happening faster than can be addressed. Regrettably, this type of information instability seems to be the price of technological convergence.

\section{En Garde!}

What seems to be missing in Howard Rheingold's 'New Social Revolution' is the full-scale adoption of mobile technologies for collective ends. Still, there continue to be those who believe that change is possible through small but consistent action. Perhaps, as McLuhan had suggested so many years ago, we must look to the periphery in order to affect change at the heart. Unlike the grandiose and probably unrealistic goal of massive change (in which designer Bruce Mau is obviously a believer), artists, thinkers, activists and cultural participators have consistently (and especially throughout the twentieth century) been committed to social and political agitation and generally 'pushing-theenvelope' in a desire to move society forward. Often, it has been those belonging to the avant-garde, as well as other 'peripheral' movements, that have participated in collective historical moments as well as heralded eras of social change. In examining the avant-garde movements of the past century, the early adoption of new technology becomes a recurring motif, along with the desire for newness - as evidenced in their manifesto-writing, which itself was borne out of a desire to be placed deliberately "between what [had] been done and what will be done, between the accomplished and the potential" (Caws, xxi). The avant-garde 
aim was to define a moment of crisis, proclaiming what action was required in order to, "oppose, to leave, to defend and to change" (Caws, xxiii).

Avant-gardism at its heart has both political and cultural dimensions, and is closely associated with art in the political programs of French utopian socialists in the beginning of the nineteenth century. Movements like Futurism, Dada, and Surrealism were primarily concerned with expressing disgust with bourgeois culture and tradition through art and the celebration of imagination. Striving for social change through primarily political action, the Situationist International (to some, the last true avant-garde movement) called for a revolution in consciousness through a transformation of the culture of everyday life. In the history of such movements, Situationism was, arguably, the most political and the least culturally co-opted. For the most part, these movements (Surrealism, Dada, etc.) have become synonymous with absurdity and nonconformist bohemian lifestyles. However, the political as well as populist urges of the Situationists, particularly through their calls to action during the student protests that took place in Paris in 1968, has allowed this movement to remain relevant, despite being almost half a century old. In the last decade, much has been written about the death of the avant-garde, especially in a time when political and social discourse has become so fractured with so many competing interests. As cultural theorists debate the nuances of this proclamation, it should be pointed out that through its relentless championing of the new, the avant-garde must inevitably face continual cycles of life and death - such is the very nature of movements that are engaged in opposition to a specific cultural moment. What continues to resonate 
about the concept of the avant-garde is the collaborative effort, the collective belief and the action taken in an effort to realize these notions. While collective action was not necessarily the hallmark of every avant-garde movement (some were solely concerned with the notion of individuality in society), the notion of 'the collective' as it relates to common ideology is certainly present. The recycling and renewing of movements that take aim at specific social or political moments allow for freshness of ideas and the consolation of new approaches informed by past failures.

Rooted firmly within the key Marxists notions of labor alienation and commodity fetishism, Situationism characterized modern capitalist society as structured by 'spectacles', made up of constructed realities that make active participation in a real, lived world of experience impossible. The alienation and resulting boredom and passivity meant that, "leisure, culture, art, information, entertainment, knowledge, the most personal and radical of gestures, and every conceivable aspect of life is reproduced as a commodity: packaged, and sold back to the consumer" (Plant, 11). In order to combat the spectacle of capitalism, the Situationist International (S.I.) prescribed political, sexual and artistic freedom as well as making "radical demands" of the imagination, creativity, desire and pleasure. The S.I. developed two distinct strategies of challenging the spectacle the theory of dérive and that of détournement, which are closely linked to the theories of the seminal French thinker, Henri Lefebvre. In his work Critique of Everyday Life, Lefebvre introduces a Marxist interpretation of the banality of everydayness (quotidienneté) as a soul-destroying process. He not only 
recognized that capitalism was structurally exploitative by nature, but also that the resulting alienation reduced anything significant or meaningful into a commodity. He was the first to propose that in order to reintroduce meaning into our lives, members of society must act on what he called "moments of revelation, emotional clarity and self-presence" (Lefebvre, 56). Moments have no precise duration but can be relived and experienced anywhere at any time. The Situationists adopted many of his theories on everyday life, and his collaboration with them in the 1960s was clearly evidenced by the wholesale appropriation of his ideas of 'moment' and 'instanteneity'. In fact, Lefebvre's theory of 'moments' had a direct influence on the S.I.'s belief in the construction of situations as an antidote to the spectacle. Particularly, Lefebvre's theories about the social relations in urban milieus, which constituted the pre-eminent site of social interaction and exchange, were of great interest to the S.I.

Currently, a newfound interest in the particular theories and actions of this avant-garde movement are of great interest to doers and thinkers alike - perhaps more so than when the movement was at its peak in 1968. Collectives such as The Critical Art Ensemble have based themselves firmly within the tradition of the S.I., and advocate collective action specifically in the form of electronic civil disobedience. Learning from the past mistakes of previous movements, the Critical Art Ensemble (CAE) believes that working within traditional strategies of dissent (the mass media, public demonstrations, etc.) no longer work, and that a more subversive, less visible approach is necessary. Encouraging clandestine activity on a 'cellular' level, this collective uses electronic information-blocking 
(and other 'hacktivist' activities) through the anonymity of the Internet to accomplish their goals. In their own manifesto, they declare that: "Those who are ready and willing to begin to form the models of electronic resistance in the new frontier of cyberspace are the ones CAE views as a new avant-garde" (CAE, 28). The CAE's objective is to bring about change through interference, effectively rendering systems of information, and the corporations that use them, ineffective. Using similar methods, an organization that calls itself ${ }^{\circledR}{ }^{\mathrm{TM}}$ ARK ('artmark') plays against systems of reputation by encouraging activism within corporate frameworks. These actions depend on the anonymity of those involved to succeed, and if the activists' identities were to be disclosed, the action would be impossible to accomplish. One of the best examples of the type of activism ${ }^{\circledR}{ }^{T M} A R K$ have done in the past was to have their members infiltrate a Mattel corporation factory which manufactures various models of their popular product, the Barbie doll. The activist infiltrators then began work on an assembly line which produced a talking doll, and began replacing the spoken message with a pre-recorded tape that denouncing commodity fetishism especially when marketed to children.

Here in Toronto, a project initiated by terminus 1525, a pilot, publicly funded project that entails a "collaborative work space brought to life on the web and on the street, fueled by the ingenuity and imagination of a new wave of Canadian creators" (www.terminus.ca). One of the many on-going projects within this umbrella organization is called murmur, "an interventionist audio art project that connects people to places." Located within the confines of the Kensington 
Market area, murmur allows the participant to explore and map this space through a series of site-specific personal stories narrated in the first person. murmur signs are placed in multiple locations within Kensington Market, where passers-by can access and listen to the stories by dialing the phone number listed on each sign. This playful recontextualizing of public and private spaces is fully within a Situationist tradition, encouraging exploratory and random locomotion in search of stories and new perceptions and experiences within a previously inactivated space. As our lives become increasingly commodified and we are subjected to previously unimaginable amounts of media and advertising, people seem to be looking for meaningful moments of participation. And as the mass demonstrations and urgent calls to vote during the recent U.S. elections have indicated, more people than ever before are acting on ideas that are important to them. While many dismiss new technologies as simply another strategy that promotes capitalist consumption, it is far more useful and interesting to look at how people use these technologies in subversive ways to do things that have been previously impossible. If anything, the smart mob and flash mob movements might spark a hope in all of us for small Gramscian victories that continue to instigate change.

\section{The Future is Slow}

As the frenetic pace of urban life threatens to push us faster and faster, the quest for a more balanced, less stressful lifestyle is becoming something that many are looking into. Borrowing from the old adage of 'The Turtle and The Hare', there is 
a movement afoot that seeks to counter the increasingly sped-up culture in which we find ourselves. In defiance of what sociologist Erving Goffman termed "the bureaucratization of the spirit", the Slow Movement rejects the notion that all people should conform to the normative pressures of society. Despite pressures to live faster and work harder, followers of the Slow movement are encouraged to acknowledge their own natural rhythms and structure their lives accordingly. The realization that the promise of flexibility through the use of mobile technology has in fact increased working hours and cut into precious leisure time has started to dawn on many people. It is estimated that the average Canadian sleeps ninety minutes less a night as compared to a century ago - yet another symptom of the current state of time-deficit in our culture (Honoré, 29). In his book In Praise of Slow: How A Worldwide Movement is Challenging The Cult of Speed, journalist and cultural commentator Carl Honoré documents significant social trends that are changing the way people live, eat, work and play. According to Honoré, the erosion of social capital is not only symptomatic of our sagging civic life, but also indicated by epidemics of obesity, chronic sleep deficits, lack of exercise, poor diet and general ill health. In his view, all these social realities are connected, and at the root of the problem lies the increasingly fast pace in which we are force to participate. The antidote to our hyper-stressed lifestyle that increasingly alienates and atomizes each one of us seems to be real-life interaction instead of technologically mediated communication and a much needed reclamation of leisure time that has been traded in the pursuit of and accumulation of material goods. 
Despite the increasing number of public space projects and activist undertakings by artist collectives and other groups, the reality is that many of these novel uses of mobile technology are being used by relatively small segments of the population. What seems to be happening is that possibilities of collective action are only being explored by those who are already engaged in participatory action and are involved in the struggle to revive democratic life in public spaces around the globe. To what extent cultural consumers use the Internet and mobile technologies to explore unfamiliar genres instead of cultivating existing tastes is still unknown. Despite the tantalizing possibilities of Rheingold's mobile social revolution, it would be wise to remain cautiously optimistic as to the true nature of mobile technologies and how they are, in fact, being used. The need to reinvigorate the commons has never been greater, especially in a time of unprecedented advancement in the number of ways we are able to communicate with one another. Currently, the perpetual contact facilitated through texting, BlackBerry and mobile phone use seems to have been harnessed primarily by advertisers looking to reach targeted audiences or by businesses requiring greater commitment to job responsibilities - often at the expense of dwindling leisure time. When faced with the possible outcomes of wholesale adoption of mobile technology, the negative aspects seem to outweigh the positive potentials:

If perpetual contact comes to be defined as normative in any and all social settings, then clearly all sorts of relationships, milieux and institutions will lose their distinctive character. Experiences from walking 
in the wilderness to worshipping to museum-going could be transformed through the loss of boundaries with the rest of participants' lives - just as "foreign" countries come to look less different from the United States, the more the weedy influences of American culture and commerce project themselves around the world. (Rule, 253)

The increased speed of information flow and acceleration of 'the consumption treadmill' has limited our ability to understand and analyze, according to culture and media theorist Scott Lash. He has the following to say about the present state of social relations: "There is an immediacy to information that has little in common with systems of belief like Christianity or the Enlightenment. The very speed and ephemerality of information leaves almost no time for reflection" (Lash, 11). A recent article in the Toronto Star seems to reinforce the idea that the current epidemic of 'info-mania' may actually serve to distract users as well as damage performance in the workplace by reducing mental sharpness. A study conducted by the University of London revealed that "constant emailing and text messaging reduces mentality capability by an average of 10 points on an I.Q. test - five points for women and 15 for men" (Toronto Star, April 23, 2005). The prevalence of 'info-mania', described as the constant checking of text and email messages, is to be taken seriously, as researchers predict it is on the rise. While the negative effects reported are temporary, the pervasive use of these kinds of mobile technologies could likely lead to more permanent effects. 


\section{Bibliography}

Altheide, David L. Creating Fear: News and the Construction of Crisis. New York: Gruyter, 2002.

Boggs, Carl. The End of Politics: Corporate Power and the Decline of the Public Sphere. New York: Gulford Press, 2000.

Boyer, Christine. City Of Collective Memory: It's Historical Imagery and Architectural Entertainments. Cambridge, MA: M.I.T. Press, 2003.

Brown, Barry, Green, Nichola, and Harper, Richard (eds). Wireless World: Social and Interactional Aspects of the Mobile Age. London: Springer, 2002.

Burt, Ronald, S. "Bandwidth and Echo: Trust, Information and Gossip in Social Networks" in Networks and Markets: Contributions From Economics and Sociology. Alessandra Casella and James E. Rauch eds. Russell Sage Foundation, 2001

Calvino, Italo. Invisible Cities. New York: Vintage, 2002.

Castells, Manuel. The Information Age: Volume II The Power Of Identity. Oxford: Blackwell Publishing, 1997.

Caws, Mary Ann. Manifesto: A Century of Isms. Lincoln: University of Nebraska Press, 2001.

Chomsky, Noam and Herman, Edward S. Manufacturing Consent: The Political Economy of Mass Media. New York: Pantheon Books, 1988. 
Courtier, Kathleen. "Broadband On the Run" in Issues In Science and Technology, (Winter 2002-03): p. 93.

Crabtree, James. "It's Time To Get Flash" in The New Statesman, (15 September 2003): p. 11.

Cummings, J., B. Butler and R. Kraut. "The Quality of Online Social

Relationships" in Communications of the ACM, 45 (7), pp.103-108.

Curran, James. "Rethinking The Media as Public Sphere" in Communication and Citizenship: Journalism and The Public Sphere. Peter Dahlgren and Colin Sparks, eds. London: Routledge: 1991. pp. 27-57.

Debord, Guy. "Theory Of Derive". Internationale Situationiste 2, Dec. 1958, and Situationist International Anthology, p.50.

Debord, Guy. The Society of the Spectacle . Donald Nicholson-Smith, trans. New York: Zone Books, 1994.

De Certeau, Michel. The Practice Of Everyday Life. Berkeley: University of California Press, 1984.

Dewey, John. The Public and Its Problems. Athens: Ohio University Press, 1954.

DiMaggio, Paul, Eszter Hargittai, W. Russell Neuman and John P. Robinson. "The Social Implications of the Internet" in Academy and the Internet. Helen Nissenbaum and Monroe E. Price eds. New York: Peter Lang Publishing, 2004.

Dixon, Terrell F. "City Places, Sacred Spaces" in Towards The Livable City. Emily Buchwald, editir. New York: Mikweed Editions, 2003. pp. 64-77. 
Dourish, Paul. Where The Action Is: The Foundation of Embodied Interaction. Cambridge: M.I.T. Press, 2001.

Eagleton, Terry. The Idea of Culture. Oxford and Cambridge, USA: Blackwell Publishing, 2000.

Gardiner, Michael. Critiques Of Everyday Life. London: Routledge, 2000.

Garnham, Nicholas. "The Mass Media, Cultural Identity, and the Public Sphere In the Modern World" in Public Culture, Volume 5, Number 2, 1993, pp. 251-265.

Gergen, Kenneth J. "The Challenge of Absent Presence" in Perpetual Contact: Mobile Communication, Private Talk, Public Performance. James Katz and Mark Aakhus, eds. Cambridge: Cambridge University Press, 2002.

Giroux, Henry A. Public Spaces, Private Lives: Beyond the Culture of Cynicism. Lanham: Rowmand and Littlefield Publishers, 2001.

Graber, Doris A, Bruce Bimber, W. Lance Bennett, Richard Davis and Pippa Norris. "The Internet and Politics: Emerging Perspectives" in Academy and the Internet. Helen Nissenbaum and Monroe E. Price eds. New York: Peter Lang Publishing, 2004.

Graham, Stephen, ed. The CyberCities Reader. London: Routledge, 2004.

Habermas, Jurgen. The Structural Transformation of the Public Sphere: An Inquiry into a Category of Bourgeois Society. Trans. Thomas Burger. Cambridge, MA: MIT Press, 1991.

Harrison, Charles and Paul Wood, eds. Art in Theory: 1900-1990 An Anthology of Changing Ideas. Oxford and Cambridge, USA: Blackwell Publishing, 1992. 
Highmore, Ben. Everyday Life and Cultural Theory: An Introduction, London: Routledge. 2001.

Honoré, Carl. In Praise of Slow: How A Worldwide Movement is Challenging the Cult of Speed. Toronto: Knopf, 2004.

Jennings, Lane. "From Virtual Communities to Smart Mobs". The Futurist (June 2003): p.6.

Klein, Naomi. No Logo: Taking Aim at the Brand Bullies. Toronto: Vintage, 2000.

Lasch, Christopher. The Culture of Narcissism: American Life in the Age of Diminishing Expectations. New York: W.W. Norton Company, 1979.

Lash, Scott. Critique of Information. London: Sage Publications, 2002.

Lefebvre, Henri. Everyday Life in the Modern World. New York: Harper and Row, 1971.

Luke, Robert. "The Phoneur: Mobile Commerce and the Digital Pedagogies of the Wireless Web" in Peter Trifonas (ed.) Communities of Difference: Culture, Language, Technology. Palgrave MacMillan, 2005.

Massumi, Brian. Parables for the Virtual: Movement, Affect, Sensation. Durham, NC: Duke University Press, 2002.

Mattelart, Armand. The Information Society: An Introduction. Trans. Susan G. Taponier and James A. Cohen. London: Sage Publications, 2003. 
Meikle, Graham. Future Active: Media Activism and the Internet. New York: Routledge, 2002.

Pendakur, Manjunath and Roma Harris (eds.) Citizenship and Participation In The Information Age. Aurora: Garamond Press, 2002.

Plant, Sadie. The Most Radical Gesture: The Situationaist International in A Postmodern Age. New York and London: Routledge, 1992.

Putnam, Robert D. Bowling Alone: The Collapse and Revival of American Community. New York: Simon and Schuster, 2000.

Rheingold, Howard. Smart Mobs: The Next Social Revolution. Cambridge: Basic Books, 2002.

Robbins, Bruce, ed. The Phantom Public Sphere. Minneapolis: U of Minnesota Press, 1993.

Rule, James B. "From Mass Society to Perpetual Contact: Models of Communication Technologies in Social Context" in Perpetual Contact: Mobile Communication, Private Talk, Public Performance. James Katz and Mark Aakhus, eds. Cambridge: Cambridge University Press, 2002.

Shapiro, Andrew L. The Control Revolution: How The Internet Is Putting Individuals In Charge And Changing The World We Know. New York: Century Foundation Books, 1999.

Soja, Edward W. Thirdspace: Journeys to Los Angeles and Other Reel and Imagined Places. Oxford: Blackwell Publishing, 1996.

Sunstein, Cass. Republic.Com. Princeton: Princeton University Press, 2001. 
Van Loon, Joost. "Social Spatialization and Everyday Life" in Space and Culture, 5 (2): 2002, 88-95.

Varoga, Craig, "Using Smart Mobs, Changing Campaign Staff." Campaigns and Elections (June 2003), Vol. 24, Issue 6, p. 49.

http:///www.boingboing.net/

http://www.critical-art.net/

http://www.dodgeball.com

http://flashmob.com/

http://www.rtmark.com

http://www.smartmobs.com/index.html

http://en.wikipedia.org/wiki/Flash_mob

http://www.wired.com 